\title{
Detection of enterotoxins produced by $B$. cereus through PCR analysis of ground and roasted coffee samples in Rio de Janeiro, Brazil
}

\author{
Detecção de enterotoxinas produzidas por B. cereus através da análise de \\ amostras de café torrado e moído da cidade do Rio de Janeiro
}

\author{
Cyllene de Matos Ornelas da Cunha Corrêa de SOUZA ${ }^{1 \star}$, Shirley de Mello Pereira ABRANTES ${ }^{2}$
}

\begin{abstract}
Coffee is one of the most appreciated drinks in the world. Coffee ground is obtained from the fruit of a small plant that belongs to the genus Coffea. Coffea arabica and Coffea canephora robusta are the two most commercially important species. They are more commonly known as arabica and robusta, respectively. Two-thirds of Coffea arabica plants are grown in South and Central America, and Eastern Africa - the place of origin for this coffee species. Contamination by microorganisms has been a major matter affecting coffee quality in Brazil, mainly due to the harvesting method adopted. Brazilian harvests are based on fruits collected from the ground mixed with those that fall on collection cloths. As the Bacillus cereus bacterium frequently uses the soil as its environmental reservoir, it is easily capable of becoming a contaminant. This study aimed to evaluate the contamination and potential of $B$. cereus enterotoxin genes encoding the HBL and NHE complexes, which were observed in strains of ground and roasted coffee samples sold in Rio de Janeiro. The PCR (Polymerase Chain Reaction) results revealed high potential of enterotoxin production in the samples. The method described by Speck (1984) was used for the isolation of contaminants. The investigation of the potential production of enterotoxins through isolates of the microorganism was performed using the $B$. cereus enterotoxin Reverse Passive Latex Agglutination test-kit (BCET-RPLA, Oxoid), according to the manufacturer's instructions. The potential of enterotoxin production was investigated using polymerase chain reaction (PCR) methods for $h b l A, h b l D$ and $h b l C$ genes (encoding hemolysin $H B L$ ) and for nhe A, nheB and nheC genes (encoding non-hemolytic enterotoxin - NHE). Of all the 17 strains, 100\% were positive for at least 1 enterotoxin gene; $52.9 \%$ (9/17) were positive for the 3 genes encoding the HBL complex; 35.3\% (6/17) were positive for the three NHE encoding genes; and $29.4 \%$ (5/17) were positive for all enterotoxic genes.

Keywords: Bacillus cereus; NHE; HBL; coffee.
\end{abstract}

\section{Resumo}

O café é uma das bebidas mais apreciadas no mundo. Os grãos de café são obtidos a partir do fruto de uma pequena planta que pertence ao gênero Coffea. Coffea arabica e Coffea canephora robusta são as duas espécies de maior importância comercial. Eles são mais comumente conhecidos como arábica e robusta, respectivamente. Dois terços das plantas de Coffea arabica são cultivados na América do Sul e Central e África Oriental (o local de origem desta espécie de café). A contaminação com micro-organismos tem sido um dos principais fatores que afetam a qualidade do café, devido ao método de colheita adotado no Brasil. As safras brasileiras são realizadas mediante a mistura à base de frutas colhidas no chão com aquelas que caem sobre panos. Como a bactéria Bacillus cereus frequentemente usa o solo como um reservatório de meio ambiente, é facilmente capaz de se tornar um contaminante. Este estudo teve como objetivo avaliar a contaminação e o potencial de genes que codificam a enterotoxina B. cereus e os complexos HBL e NHE, que foram observados em cepas de amostras de café torrado e moído comercializado no Município do Rio de Janeiro. Os resultados de PCR revelaram o alto potencial de produção de enterotoxinas em amostras. O método descrito por Speck (1984) foi utilizado para o isolamento de contaminantes de solo e de café torrado. A investigação do potencial de produção de enterotoxinas por isolados dos microrganismos foi realizada através do enterotoxina B. cereus reversa passiva em látex kit de teste de aglutinação (BCET-RPLA, Oxoid), de acordo com instruções do fabricante. O potencial de produção de enterotoxinas foi investigado através de reação em cadeia da polimerase (PCR) para os genes hblA, hblD e hblC (que codifica a hemolisina BL) e para os genes nheA, nheB e nheC (codificador da enterotoxina não hemolítica - NHE). Do total de 17 cepas, 100\% foram positivas para pelo menos um gene da enterotoxina, 52,9\% (17/09) foram positivas para os três genes que codificam o complexo HBL, 35,3\% (17/06) foram positivas para os três genes da NHE e 29,4\% (17/05) foram positivas para todos os genes enterotoxigênicas.

Palavras-chave: Bacillus cereus; NHE; HBL; café.

\section{Introduction}

Bacillus cereus is a Gram-positive bacterium that can live in both anaerobic and aerobic conditions. B. cereus is also mesophilic and produces at least two types of toxins that are important in the symptomatology of food-borne illnesses: diarrheic (heat-labile) and emetic (heat-stable) toxins. These bacteria can be found in a variety of foods, such as meat, fish,

Programa de Pós-graduação em Ciência e Tecnologia de Alimentos - PPGCTA, Universidade Federal Rural do Rio de Janeiro - UFRRJ, Rod. BR 465, Km 7, CEP 23890-000, Seropédica - RJ, E-mail: cyllenematos@gmail.com

${ }^{2}$ Fundação Oswaldo Cruz, Instituto Nacional de Controle de Qualidade de Saúde - INCQS, Av. Brasil, 4365, Manguinhos, CEP 21040-900, Rio de Janeiro - RJ, Brasil

${ }^{*}$ Corresponding author 
milk and its derivatives, and raw foods, including fruits and vegetables (HARMON et al. 1992), both dry and processed (DOYLE, 1998).

It is difficult to eliminate microorganisms from the industrial environment (HARMON; GOEPFERT; BENNETT, 1992), because many spores are able to survive at different temperatures and $\mathrm{pH}$ levels. Spores are often resistant to dehydration and irradiation and present a notable capacity of adherence to food surfaces (BACHHIL; JAISWAL, 1988).

B. cereus is frequently isolated from uncooked and unprocessed products, such as rice, condiments, vegetables, meat, and milk products. This microorganism is associated with two food-borne illnesses, called "emetic syndrome" and "diarrheic syndrome." Its colonies can be identified by their irregular morphology; they are albescent and generally shiny. B. cereus uses glucose as a carbon source, instead of mannitol, arabinose, or xylose, and is able to hydrolyze starch and gelatin. It is positive for lecithinase and exhibits hemolytic activity and resistance to ampicillin (AGATA; OHTA; YOKOYAMA, 2002).

B. cereus secretes a set of extracellular enzymes and toxins that are considered important factors because of their pathogenicity. Two enterotoxins, HBL and NHE each formed by three components, are currently considered to be the main agents of diarrheic infection in food poisoning cases caused by $B$. cereus. Hemolytic activity, cytotoxicity and vascular dermonecrosis, together with permeability and fluid accumulation in rabbit ileal loops, are symptoms associated with the enterotoxins detected in filtered cultures of toxigenic B. cereus strains (BEECHER et al., 2001).

The hemolysin $\mathrm{BL}(\mathrm{HBL})$ is composed of a binding component (B) and two lytic components, $\mathrm{L}_{1}$ and $\mathrm{L}_{2}$, transcribed from the genes $h b l A, h b l D$, and $h b l C$, respectively. All three genes are required for maximal activity. The NHE complex is also comprises three different proteins, NheA, NheB, and NheC, encoded by the three genes nheA, nheB, and nheC (GRANUM; O'SULLIVAN; LUND, 1999). In both cases, the genes for each toxin's three components are found as an operon.

The non-hemolytic enterotoxin (NHE) is the second threecomponent enterotoxin responsible for diarrhea caused by B. cereus food poisoning. NHE is composed of NheA, NheB, and NheC. The three genes encoding the NHE components constitute an operon. The hemolytic enterotoxin, HBL, is encoded by the $h b l C D A$ operon and is composed of three protein components, $\mathrm{L} 1, \mathrm{~L} 2$, and $\mathrm{B}$. The $\mathrm{B}$ component mediates binding; L1 and L2 are lytic components (RYAN; MCMILLAN; ZILINSKAS, 1997). This toxin also has dermonecrotic and vasculature permeabilizing activities and causes fluid accumulation in rabbit ileal loops (TSEN et al., 2000).

B. cereus contamination of ground and roasted coffee may occur due to the presence of the strain in the soil, where it adheres to coffee plants. Due to its ability to sporulate, $B$. cereus can survive the roasting process (LUND; GRANUM, 1996). The infectious dose of $B$. cereus ranges from $10^{4}$ to $10^{11}$ cells per gram of food. The exact value depends on a number of factors, including the presence of viable cells or spores in the food, on the amount of enterotoxin(s) produced, as well as on the susceptibility of the target population (BEECHER; SCHOENI; WONG, 1995).

It is believed that all individuals are susceptible to $B$. cereus food poisoning; however, more severe symptoms have been associated with young adults and the elderly (GHELARDI et al., 2002).

\section{Materials and methods}

\subsection{Sampling}

Ten different brands of ground and roasted coffee were analyzed. Three different samples of each brand were collected for analysis. The isolation of viable cells from the samples and their subsequent quantitation were performed as described by (VASCONCELLOS; RABINOVITCH, 1994). Cytomorphologic, biochemical, and physiologic identification was carried out according to the protocols of Gordon, Haynes and Pang (1973), Claus and Berkeley (1986).

\subsection{Isolation and enumeration of B. cereus sensu lato strains}

The method described by Speck (1984) was also used in the isolation of contaminants from ground roasted coffee. First, $1 \mathrm{~g}$ of ground and roasted coffee was homogenized manually in an Erlenmeyer flask containing $10 \mathrm{~mL}$ of phosphate buffer ( $\mathrm{pH} 7.0)$. After homogenization, $2 \mathrm{~mL}$ of the suspension was transferred to a $10-\mathrm{mL}$ sterile tube and heated at $65^{\circ} \mathrm{C}$ for 5 minutes. After cooling, $1 \mathrm{~mL}$ was transferred to a $10-\mathrm{mL}$ test tube containing $9 \mathrm{~mL}$ of sterile, distilled water, and 3 serial ten-fold dilutions were generated.

Detection and enumeration of cultured bacteria were performed through plating on selective solid medium. VRM medium, which allows for visualization of the hydrolysis of egg lecithin, was designed by Vasconcellos and Rabinovitch (1994) and has been adopted by the Laboratório de Fisiologia Bacteriana" as a selective medium for the B. cereus family. Cultures were incubated at $33^{\circ} \mathrm{C}$ for 24 hour, during this period of time many colonies were surrounded by cloudy haloes, caused by the hydrolysis of lecithin. These colonies were pale pink, in contrast to the more intense pink that characterizes the rest of the medium. They were considered to be positive for lecithinase activity and were subsequently enumerated.

The number of lecithinase-positive B. cereus sensu lato colonies was calculated based on viable spore counts, and the results were expressed as colony forming units (CFU) per gram of analyzed sample. Only colonies without parasporal crystalline inclusions (visible under phase-contrast microscopy) were classified as $B$. cereus sensu stricto, whereas those with parasporal crystalline inclusions were determined to be B. thuringiensis.

Positive colonies from each sample were then streaked onto nutrient agar and were subsequently confirmed to be 
B. cereus s.s. by phenotypic testing. They were then streaked in nutrient agar slants and refrigerated as pure cultures.

\subsection{Phenotypic identification and confirmation of strains as B. cereus sensu stricto}

Isolates of B. cereus s.s. were identified by Gram staining, hemolytic activity, and specific biochemical, physiologic, and cytomorphologic tests for taxonomic studies of bacteria belonging to the genus Bacillus, according to the protocols of Gordon; Haynes and Pang (1973), Gibson and Gordon (1974), Claus and Berkeley (1986), and Vasconcellos and Rabinovitch (1995).

\subsection{Detection of the hemolysin BL enterotoxin}

Hemolysin BL (HBL) enterotoxin production was assessed through the detection of the $\mathrm{L}_{2}$ lytic fraction of the HBL complex, using the B. cereus Enterotoxin Reverse Passive Latex Agglutination test-kit (BCET-RPLA, Oxoid), according to the manufacturer's instructions. This test allows for the detection of toxins as soluble antigens in an agglutination assay.

\subsection{Production of diarrheal enterotoxins in bacterial cells}

B. cereus strains were inoculated in $3 \mu \mathrm{L}$ of Heart Infusion Broth (Oxoid) supplemented with $1 \%$ glucose (HIB broth) and incubated at $33^{\circ} \mathrm{C}+1{ }^{\circ} \mathrm{C}$ for 4 hours. After this period, $100 \mu \mathrm{L}$ was inoculated into $25 \mathrm{~mL} \mathrm{HIB}$, incubated at $33^{\circ} \mathrm{C}+1{ }^{\circ} \mathrm{C}$, and agitated at $175 \mathrm{rpm}$ for a period of 18 to 20 hours. Finally, each strain was centrifuged at $2,200 \mathrm{rpm}$ for 20 minutes at $10^{\circ} \mathrm{C}$. The centrifuged material (both pellets and supernatants) were kept under refrigeration until use.

Microplates for microagglutination were organized in rows comprising eight wells. Two rows were used for each sample. Using a micropipette, $25 \mu \mathrm{L}$ of diluent (TD 954) was dispensed into each well of 2 rows, except for the first well in each row. Next, $25 \mu \mathrm{L}$ of the sample to be tested was added to the first and second wells of both rows. Starting at the second well of each row, $25 \mu \mathrm{L}$ was pipetted and diluted two-fold into the next well in the row. This process was continued along each row through the seventh well; the last well contained only diluent.
Each well in the first row received $25 \mu \mathrm{L}$ of sensitized latex (TD 951), and each well in the second row received $25 \mu \mathrm{L}$ of latex control (TD 952). Manual agitation was used to homogenize the content of each well. The plates were covered to avoid evaporation. Inoculated plates were left undisturbed on a vibration-free surface at room temperature. After 24 hours, the wells in each row were examined for agglutination against a black background. The amount of enterotoxin produced was determined using index values derived from the Oxoid reading scale.

\subsection{Polymerase chain reaction (PCR) analysis of enterotoxin genes}

All strains were tested for the presence of the hblCDA and nhe $A B C$ genes with primers designed by Hansen and Hendriksen (2001), as listed in Table 1. A total genomic DNA for PCR analysis, extracted by boiling, was prepared from overnight cultures of $B$. cereus isolates in Luria-Bertani medium, as described by Nunes et al. (1999). PCR amplifications were performed in an MJ Research thermocycler with PCR conditions as follows: a single denaturation step at $94{ }^{\circ} \mathrm{C}$ for 2 minutes; 30 cycles with denaturation at $94^{\circ} \mathrm{C}$ for 15 seconds; annealing at $55^{\circ} \mathrm{C}(h b l A, h b l D$, nhe $A$, and $n h e C)$ or $50^{\circ} \mathrm{C}(h b l C$ and $n h e B$ ) for 45 seconds; extension at $72^{\circ} \mathrm{C}$ for 30 seconds; and a final extension step at $72^{\circ} \mathrm{C}$ for 4 minutes. Each $25-\mu \mathrm{L}$ reaction mixture contained $200 \mu \mathrm{m}$ dNTP mix solution; $1.5 \mathrm{mM} \mathrm{MgCl}_{2}$, $50 \mathrm{ng}$ of template DNA; $0.5 \mu \mathrm{L}$ of each primer; and $1.0 \mathrm{U}$ of Taq DNA polymerase (Invitrogen). B. cereus ATCC 14579 was used as positive control. Amplicons were electrophoresed in $1.5 \%$ agarose gels in Tris-borate EDTA buffer $(0.5 \times$ TBE; $89 \mathrm{mM}$ Tris-borate, $2 \mathrm{mM}, \mathrm{EDTA}, \mathrm{pH} 8.0$ ) at $90 \mathrm{~V}$ for 35 minutes. Products were visualized under ultraviolet light after 10 minutes of treatment with $0.5 \mu \mathrm{g} \cdot \mathrm{mL}^{-1}$ ethidium bromide solution. As a reference, a 100-bp DNA ladder (Amersham Pharmacia Biotech) was used.

\section{Results}

To assess the level of ground and roasted coffee contamination by B. cereus s.s., 30 samples from 10 distinct manufacturers were analyzed using viable spore counting analysis. Although the occurrence of $B$. cereus in the ground and roasted coffee was relatively high (56.7\%), the bacterial counting of B. cereus

Table 1. Polymerase chain reaction (PCR) primers used in this study.

\begin{tabular}{|c|c|c|c|c|c|}
\hline Primers & Target genes & Primer Sequence $\left(5^{\prime}-3^{\prime}\right)$ & Positions $\left(5^{\prime}-3^{\prime}\right)$ & Product size (bp) & References \\
\hline hblA1 & hblA & GTGCAGATGTTGATGCCGAT & $671-690$ & 320 & Hansen and Hendriksen (2001) \\
\hline hblA2 & & ATGCCACTGCGTGGACATAT & $990-971$ & & \\
\hline L1A & $h b l D$ & AATCAAGAGCTGTCACGAAT & $2854-2873$ & 430 & \\
\hline L2A & $h b l C$ & AATGGTCATCGGAACTCTAT & $1448-1467$ & 750 & \\
\hline L2A & & CTCGCTGTTCTGCTGTTAAT & $2197-2178$ & & \\
\hline nheB-S & nheB & CTATCAGCACTTATGGCAG & $1500-1518$ & 770 & \\
\hline nheB-A & & ACTCCTAGCGGTGTTCC & $2269-2253$ & & \\
\hline nheC-S & nheC & CGGTAGTGATTGCTGGG & $2820-2836$ & 582 & \\
\hline nheC-A & & CAGCATTCGTACTTGCCAA & $3401-3383$ & & \\
\hline
\end{tabular}


isolates in the samples were low. As shown in Table 2, the average numbers of $B$. cereus s.l. in ground and roasted coffee ranged from $10^{1}$ to $10^{3} \mathrm{CFU} \cdot \mathrm{g}^{-1}$. Isolated colonies of B. cereus s.s. were initially identified based on their lecithinase-positive morphology on plates; their cellular appearance as viewed by light microscopy; and their production of subterminal and cylindrical spores. Table 3 presents the identification parameters obtained by the phenotypic tests. Nevertheless, some strains demonstrated characteristics different from the reference strain B. cereus ATCC 14579. For example, some isolates showed phenotypes distinct from the reference strain in terms of growth in Nutrient Broth containing 5\% and 7\% $\mathrm{NaCl}$ and acetyl-methyl-carbinol production (Voges-Proskauer reaction). All the isolates were $\beta$-hemolytic, but three isolates did not decompose L-tyrosine. Additionally, 5 out of the $17 \mathrm{~B}$. cereus s.s. strains were unable to degrade starch, and 8 isolates were able to grow at $40^{\circ} \mathrm{C}$.
The production of the selected protein component $\left(\mathrm{L}_{2}\right.$ lytic fraction), and the presence of selected genes encoding proteins involved in B. cereus-related diarrhea are listed in Table 3. According to the presence of various enterotoxin genes, the 17 B. cereus s.s. isolates could be divided into 7 groups. All six genes were detected in group I. Groups II and III did not contain nhe $A$ and $h b l A$, respectively. The $h b l A$ and $n h e C$ genes were not detected in group IV. Group V did not contain the $h b l A$ and nhe AC genes, while groups VI and VII both lacked $h b l C D A$ as well as nheAC and nheA, respectively.

The presence of six enterotoxic genes was detected by PCR in all B. cereus isolates. Of all 17 strains, $100 \%$ were positive for at least 1 enterotoxin gene; $52.9 \%(9 / 17)$ were positive for the 3 genes encoding the HBL complex; $35.3 \%(6 / 17)$ were positive for the 3 genes encoding the NHE complex; and $29.4 \%$ (5/17) were positive for all enterotoxic genes (Figure 1). The 17 isolates characterized as B. cereus s.s. were also tested

Table 2. Average Bacillus cereus sensu lato counts obtained from different manufacturers of roasted and ground coffee.

\begin{tabular}{ccccc}
\hline Roasted and ground coffee of lots & $\mathrm{N}^{\circ}$ of samples & Average counts (cfu.g $\left.{ }^{-1}\right)^{\star}$ & $\begin{array}{c}\mathrm{N}^{\circ} \text { of samples containing } \\
\text { B. cereus s.l. }\end{array}$ & $\begin{array}{c}\text { \% of samples containing } \\
\text { B. cereus s.l. }\end{array}$ \\
\hline $1^{\circ}$ & 10 & $10^{1}$ to $10^{3}$ & 4 & 40 \\
$2^{\circ}$ & 10 & $10^{1}$ to $10^{2}$ & 4 & 40 \\
$3^{\circ}$ & 10 & $10^{2}$ to $10^{3}$ & 9 & 80 \\
\hline
\end{tabular}

${ }^{\star} \mathrm{CFU} \cdot \mathrm{g}^{-1}-$ colony forming units per gram of analyzed sample.

Table 3. Occurrence of genes encoding enterotoxins and phenotypic characteristics of isolated Bacillus cereus sensu stricto from roasted and ground coffee.

\begin{tabular}{|c|c|c|c|c|c|c|c|c|c|c|c|c|c|c|}
\hline \multirow[t]{3}{*}{ B. cereus s.s. } & \multicolumn{8}{|c|}{ Enterotoxins } & \multirow{2}{*}{\multicolumn{6}{|c|}{$\begin{array}{l}\text { Some differences in biochemical } \\
\text { and physiologic characters }\end{array}$}} \\
\hline & \multicolumn{3}{|c|}{ HBL genes $^{1}$} & \multicolumn{3}{|c|}{ NHE genes $^{1}$} & \multirow[t]{2}{*}{ Group } & \multirow{2}{*}{$\begin{array}{l}\mathrm{L}_{2} \text { Lytic Fraction } \\
(\text { RPLA-BCET })^{2}\end{array}$} & & & & & & \\
\hline & hbla & $h b l C$ & $h b l D$ & nheA & nheB & nheC & & & AMI & $\mathrm{VP}$ & $\mathrm{NaCl} 5 \%$ & $\mathrm{NaCl} 7 \%$ & TIR & $40^{\circ} \mathrm{C}$ \\
\hline 5.2 & + & + & + & + & + & + & I & +++ & + & - & - & - & + & - \\
\hline 7.2 & + & + & + & + & + & + & I & +++ & + & - & + & + & + & - \\
\hline 9.2 & + & + & + & + & + & + & I & +++ & + & - & - & - & + & + \\
\hline 6.1 & + & + & + & - & + & + & II & +++ & + & - & + & + & + & - \\
\hline 7.1 & + & + & + & - & + & + & II & +++ & + & - & + & + & + & + \\
\hline 9.1 & + & + & + & - & + & + & II & +++ & + & - & + & + & + & - \\
\hline 9.3 & - & + & + & + & + & + & III & +++ & + & + & + & - & - & - \\
\hline 6.3 & - & + & + & + & + & - & IV & +++ & + & + & + & + & + & - \\
\hline 8.3 & - & - & - & - & + & - & VI & - & - & + & + & + & + & + \\
\hline 3.3 & - & - & - & - & + & + & VII & - & - & + & + & + & + & + \\
\hline 7.3 & - & - & - & - & + & + & VII & - & - & + & + & + & + & + \\
\hline Total $n^{\circ}$ of isolates $(n=17)$ & 9 & 12 & 12 & 7 & 17 & 12 & 7 & 12 & 12 & 10 & 14 & 11 & 14 & 8 \\
\hline \multicolumn{15}{|c|}{ Reference Strain B. cereus NCTC 2599} \\
\hline $\begin{array}{l}\text { +, positive; - , negative; }{ }^{1}+\text {, a PCR } \\
- \text {, absence of diarrheal enterotoxi } \\
\text { in Nutrient Broth containing } 5 \% \\
\text { results for: utilization of citrate, c } \\
\text { reaction. All isolated B. cereus stra } \\
\text { and mannitol, and gas production }\end{array}$ & $\begin{array}{l}\text { product } \\
1 ;{ }^{3} \mathrm{See} \mathrm{C} \\
\mathrm{NaCl} ; \mathrm{Na} \\
\text { sein hyc } \\
\text { ins prese }\end{array}$ & $\begin{array}{l}\text { of the ex } \\
\text { laus and } \\
\mathrm{Cl} 7 \%= \\
\text { Irolysis, } \\
\text { nted neg }\end{array}$ & $\begin{array}{l}\text { cted si } \\
\text { rkeley } \\
\text { owth } \\
\text { thina }\end{array}$ & $\begin{array}{l}\text { was obs } \\
986) ;{ }^{4} \mathrm{~A} \\
\% \mathrm{NaC} \\
\text { eaction } \\
\text { for the }\end{array}$ & $\begin{array}{l}\text { red; - } \\
\text { II = } \\
\text { IR = } \\
\text { atalas }\end{array}$ & $\begin{array}{l}\text { PCR } \\
\text { hyd } \\
\text { sine } \\
\text { oduct }\end{array}$ & $\begin{array}{l}\text { roduct W } \\
\text { olysis; Vl } \\
\text { egradatic } \\
\text { on, anaer }\end{array}$ & $\begin{array}{l}\text { observed; }{ }^{2}+++ \text {, pro } \\
=\text { Voges-Proskauer te } \\
\text { Temp. } 40^{\circ} \mathrm{C}=\text { grow } \\
\text { ic growth, acid prod } \\
5{ }^{\circ} \mathrm{C} \text {, and } 65^{\circ} \mathrm{C} \text {, grow }\end{array}$ & $\begin{array}{l}\text { tion of } \\
\text { acetyl- } \\
\text { it } 40^{\circ} \mathrm{C} \\
\text { ion fro }\end{array}$ & $\begin{array}{l}\text { f diarrh } \\
\text { methyl } \\
\text {; }{ }^{5} \text { All i } \\
\text { m gluc }\end{array}$ & $\begin{array}{l}\text { leal enterotox } \\
\text { l-carbinol pr } \\
\text { isolated } B \text {. ce } \\
\text { ose, product } \\
\text { acid product }\end{array}$ & $\begin{array}{l}\text { in detected by } \\
\text { oduction); } \mathrm{Na} \\
\text { reus strains pr } \\
\text { ion of hemoly } \\
\text { ion from } \mathrm{D}-\mathrm{xy}\end{array}$ & $\begin{array}{l}\text { y the } \mathrm{O} \\
\mathrm{Cl} 5 \% \\
\text { esented } \\
\text { sis, and }\end{array}$ & $\begin{array}{l}\text { roid test; } \\
\text { growth } \\
\text { positive } \\
\text { oxidase } \\
\text { abinose, }\end{array}$ \\
\hline
\end{tabular}




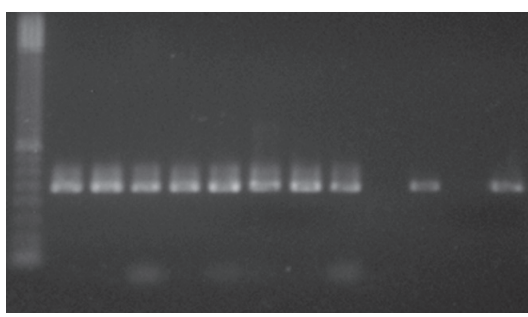

nhe A

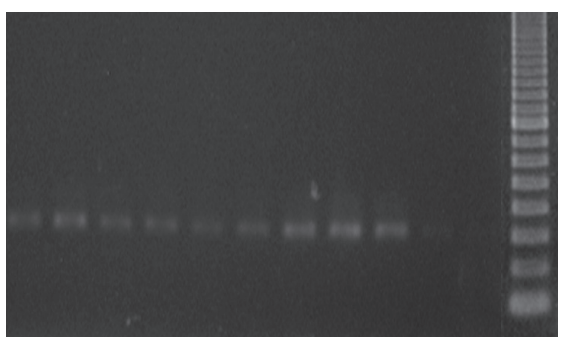

hbl A

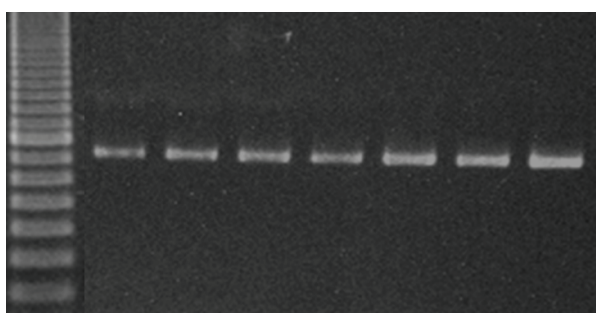

nhe $B$

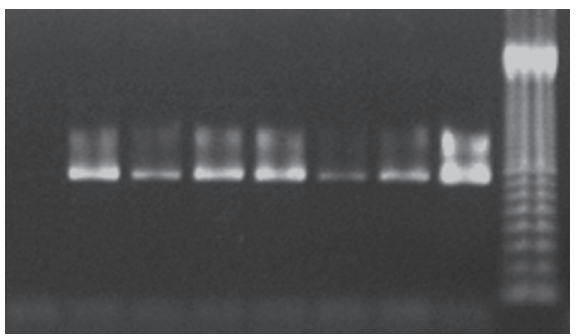

hbl C

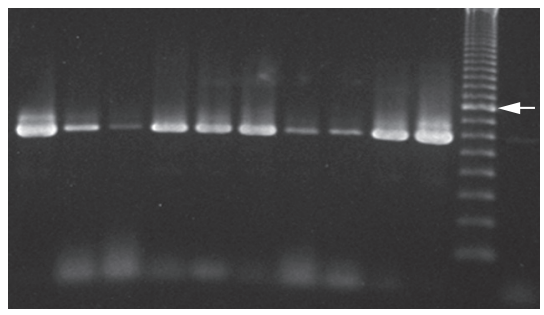

nhe $C$

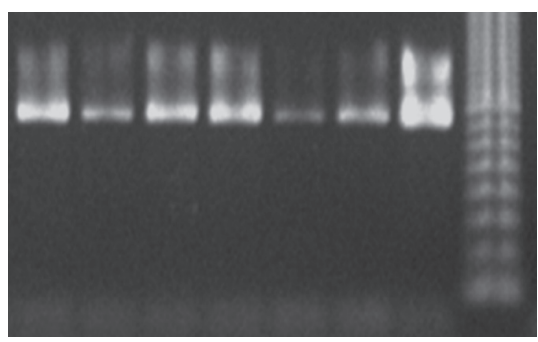

$h b l D$
$800 \mathrm{bp}$

Figure 1. Representative PCR results from isolated Bacillus cereus. (A) Agarose gel of PCR products for the $n h e A$, $n$ he $B$, and $n h e C$ genes encoding "Nonhemolytic Enterotoxin," NHE; (B) Agarose gel of PCR products for the $h b l A, h b l C$, and $h b l D$ genes encoding "Hemolysin BL," HBL.

for diarrheal enterotoxin production; 12 strains $(70.6 \%)$ were positive, and 5 strains $(29.4 \%)$ were negative, using the BCETRPLA test (Table 3). All 12 hblC PCR-positive strains were also enterotoxin-producing strains.

The occurrence of each enterotoxin gene in the B. cereus s.s. isolates was as follows: $h b l A(52.9 \%), h b l C(70.6 \%), h b l D$ (70.6\%), nheA (41.2\%), nheC (70.6\%), and nheB - detected in all analyzed isolates.

These results showed that all strains examined possessed genes or protein components for toxins involved in human diarrheal disease. The consequence of this finding, in terms of food safety regulations, remains to be evaluated.

\section{Discussion}

The results described in this report may have relevant consequences. The microbiological parameters defined by the Brazilian legislation on January $2^{\text {nd }}, 2001\left(R D C n^{\circ} 12\right)$ (BRASIL, 2001) did not establish tolerance levels for B. cereus s.s. in ground and roasted coffee. Until now, there is no tolerance limits established for B. cereus in coffee, despite the potential of this bacterium to cause food-borne illness.

However, they established limits for other similar foods such as tea (Mate, Ilex paraguariensis). In the RDC ${ }^{\circ} 175$ of July $8^{\text {th }}$, 2003 (BRASIL, 2003), samples from foods carrying B. cereus or other microorganisms were, at least, unsatisfactory, since these microorganisms can cause serious health problems. In the present study, the average counting of B. cereus-like bacteria detected in samples of ground and roasted coffee revealed the presence of this pathogen in 17 out of 30 analyzed samples (incidence of 56.7\%). It should be emphasized that the Brazilian legislation (BRASIL, 2003) has set a limit of $10^{3} \mathrm{CFU} \cdot \mathrm{g}^{-1}$ for $B$. cereus in mate tea, which is prepared similarly to coffee. If similar limits were set for coffee, the results here demonstrate that many commercial brands of coffee would be considered unsuitable for consumption.

The B. cereus detection frequency in coffee samples suggests a widespread distribution of this microorganism throughout the several steps of coffee production. The identification of vine plants carrying enterotoxins indicates that contamination may occur from tilling. This particular result also indicates that the control of this microorganism must occur from the beginning of the coffee processing - the harvesting. An appropriate healthy harvesting process will reduce the risk of food-borne illnesses associated with B. cereus (DAGLIA et al., 2007).

The presence of B. cereus in ground and roasted coffee may be due to several factors, including the elevated heat-resistance of spores, the application of thermally unsuitable treatments in the coffee-roasting house, and the storage at inappropriate temperatures (YEN et al., 2005).

The HBL and NHE enterotoxins are the primary cause of diarrhea after infection by B. cereus from contaminated foods. Actually, an immunoassay method to identify diarrhoeal enterotoxin in $B$. cereus is being using for foods. The BCETRPLA kit, which detects the hemolytic fraction $\mathrm{L}_{2}$ (HBLC), has been used to assess the production of this toxin by members of the B. cereus group (GUINEBRETIËRE; BROUSSOLLE; NGUYEN-THE, 2002). Among the 17 tested strains, 12 (70.6\%) were found to synthesize the proteic sub-unit $\mathrm{L}_{2}$, as indicated by the BCET-RPLA index. For the 17 B. cereus strains, $h b l C$ gene detection through PCR method correlated well with the results of BCET-RPLA test.

All seventeen $B$. cereus tested strains possessed at least one gene or component of the HBL and NHE complex. A high occurrence of protein components and/or genes involved in human diarrhoeal disease has previously been described for $B$. 
cereus from foods (GAVIRIA-RIVERA; GRANUM; PRIEST, 2000; VALERO et al., 2002; ROSENQUIST et al., 2005).

The percentage of food poisoning outbreaks associated with B. cereus varies from country to country, and it is dependent on the reporting system. In Japan, the emetic type is reported about 10 times more frequently than the diarrhoeal type; while in Europe and North America, the diarrhoeal type is the most frequently reported (KOTIRANTA; LOUNATMAA; HAAPASALO, 2000). In the Netherlands, for example, from 1991 to 1994, B. cereus was identified as the most common cause (19\%) of food poisoning outbreaks (SIMONE et al., 1997). Mead et al. (1999) estimated that more than 27,000 food-borne illnesses are caused by B. cereus the United States annually. However, very little is known about food poisoning outbreaks in Central and South America. A better knowledge of the characteristics of these strains that cause food-borne illnesses by $B$. cereus would help to establish their risk and provide information for microbiological risk evaluation.

Out of the 17 B. cereus strains, 5 lacked the three genes from the HBL operon and the remaining 12 strains had at least two genes of the HBL complex. B. cereus strains with incomplete HBL complex have been reported (MÄNTYNEN; LINDSTRÖM, 1998). Three strains were negative for $h b l A$ gene and positive for $h b l C D$ genes in the PCR. This indicates that the $h b l A$ gene is present in these strains, but one of the primer binding sites was probably modified (PRÜSS et al., 1999).

Recent studies using PCR-based methods (GHELARDI et al., 2002; PHELPS; McKILIP, 2002) have attested the heterogeneity of $B$. cereus and the presence of virulence factors carried by the pathogen.

Hansen and Hendriksen (2001) reported that the functioning of the HBL complex depends on products from all three genes, and it is most likely that polymorphism among the genes causes the inability to detect all genes in some strains through PCR. Polymorphism similar results in the hbl or nhe operon were reported by Guinebretière, Broussolle and Nguyen-The (2002) among diarrheal B. cereus strains.

Hsieh et al. (1999) investigated the virulence profiles of $B$. cereus s.l. group bacteria, including B. cereus strains isolated from foods and samples associated with food-poisoning outbreaks. For this investigation, the presence of enterotoxin genes were assayed through PCR methods and the authors concluded that all $B$. cereus group strains may be potentially toxigenic- that is why the detection of these strains in foods is important.

Among the six tested genes, nheB, coding for the $39-\mathrm{kDa}$ component of NHE complex, was the most frequent, detected in all $B$. cereus strains through PCR. In contrast, the percentage of strains harboring nheA was smaller (41.2\%) among the isolated strains. Because all the nhe genes belong to the same operon (GRANUM; O'SULLIVAN; LUND, 1999), it is, however, possible that the negative nheAC-PCR results were due to gene polymorphism rather than to its absence (LUND; GRANUM, 1996).
In groups VI and VII, there are five strains of B. cereus (29.4\%) that did not allow the amplification of the HBL complex genes, but hemolytic activity by producing $\beta$-like hemolysis was demonstrated. This is in agreement with the evidence that several hemolytic factors are expressed in the B. cereus group, such as cereolysin, sphingomyelinase, cereolysin $\mathrm{AB}$, and cereolysin-like hemolysin (PRÜSS et al., 1999). These strains were not able to degrade starch, and grew at $40{ }^{\circ} \mathrm{C}$. Thus, they could be $B$. cereus strains producing emetic toxin that is usually unable to degrade starch (VALERO et al., 2002; AGATA; OHTA; MORI, 1996).

Biochemical features such as starch hydrolysis, acetylmethyl-carbinol production, and tyrosine degradation, presented discriminative results, what demonstrated that isolated strains with different biochemical metabolism may be strains derived from diverse contamination sources. Germination of $B$. cereus strains take advantage between $10^{\circ} \mathrm{C}$ and $48{ }^{\circ} \mathrm{C}$, and temperatures lower than $100{ }^{\circ} \mathrm{C}$ cannot be efficient to the destruction of $B$. cereus spores. This bacterium is not a competitive organism and geminates well in foods containing flour or starch; in particular, boiled rice after cooling (below $48^{\circ} \mathrm{C}$ ) can enable the growth of this microorganism. After heating, with the absence of a competitive flora, the spores geminate and can produce toxins (SILVA et al., 2007).

The higher the number of samples containing enterotoxigenic B. cereus strains, the higher the necessity of improvements in hygiene conditions during the processing of coffee, so that risks to the public health can be avoided.

\section{Acknowledgements}

I am very grateful to Clara Fatima Cavados - Institute 'Oswaldo Cruz' for kindly giving in some space in the Laboratory of Bacterial Physiology, as well as to the Jeane Quintanilha for the help with the inquiries.

\section{References}

AGATA, N.; OHTA, M.; MORI, M. Production of an emetic toxin, cereulide, is associated with a specific class of Bacillus cereus. Current Microbiology, v. 33, p. 67-69, 1996. http://dx.doi. org/10.1007/s002849900076

AGATA, N.; OHTA, M.; YOKOYAMA, K. Production of Bacillus cereus emetic toxin (cereulide) in various foods. International Journal of Food Microbiology, v. 73, p. 23-27, 2002. http://dx.doi.org/10.1016/ S0168-1605(01)00692-4

BACHHIL, V. N.; JAISWAL, T. N. Bacillus cereus in meats: incidence, prevalence and enterotoxigenicity. Journal Food Science and Technology, v. 25, n. 6, p. 371-372, 1988.

BEECHER, D. J.; SCHOENI, J. L.; WONG, A. C. L. Enterotoxin activity of hemolysin BL from Bacillus cereus. Infection and Immunity, v. 63, p. 4423-4428, 1995.

BEECHER, D. J.; MACMILLAN, J. D. Characterization of the components of hemolysin BL from Bacillus cereus. Infection and Immunity, v. 59, p. 1778-1784, 2001.

BRASIL. Ministério da Saúde. Agência Nacional de Vigilância Sanitária. Resolução - RDC n. 12, de 2 janeiro de 2001. Aprova Regulamento Técnico sobre padrões microbiológicos para alimentos. Diário Oficial da República Federativa do Brasil, Brasília, DF, 10 jan. 2001. 
BRASIL. Ministério da Saúde. Agência Nacional de Vigilância Sanitária. Resolução - RDC n. 175, 8 de julho de 2003. Aprova "Regulamento Técnico de Avaliação de Matérias Macroscópicas e Microscópicas em alimentos". Diário Oficial da República Federativa do Brasil, Brasília, DF, 6 jul. 2003.

BRYAN, F. L. Systems for retail food and restaurant operations. Journal of Food Protection, v. 53, p. 978-983, 1990.

CLAUS, D.; BERKELEY, R. C. W. Genus Bacillus Cohn 1872. In: SNEATH, P. H. A. et al. Bergey's Manual of Systematic Bacteriology. 2th ed. Baltimore: Williams \& Wilkins, 1986. p. 1104-1139.

DAGLIA, M. et al. Isolation, identification, and quantification of roasted coffee antibacterial compounds. Journal of Agricultural and Food Chemistry, v. 55, p. 10208-10213, 2007. PMid:18001036. http:// dx.doi.org/10.1021/jf0722607

DOYLE, M. P. Bacillus cereus. Food Technology, v. 42, n. 4, p. 199-200, 1998.

GAVIRIA-RIVERA, A. M.; GRANUM, P. E.; PRIEST, F. G. Common occurrence of enterotoxin genes and enterotoxicity in Bacillus thuringiensis. FEMS Microbiology Letters, v. 190, p. 151-155, 2000. http://dx.doi.org/10.1111/j.1574-6968.2000. tb09278.x

GHELARDI, E. et al. Identification and characterization of toxigenic Bacillus cereus isolates responsible for two food-poisoning outbreaks. FEMS Microbiology Letters, v. 208, p. 129-134, 2002. PMid:11934506. http://dx.doi.org/10.1111/j.1574-6968.2002. tb11072.x

GIBSON, T. .; GORDON, R,E. Endospore-forming Rods and Cocci. In: BUCHANAN, R. E.; GIBSONS, N. E. (Ed). Bergey's Manual of Determinative Bacteriology. 8th ed. Baltimore: Wiliiams \& Wilkins Co., 1974. p. 529-575.

GORDON, R. E.; HAYNES, W. C.; PANG, C. N. The Genus Bacillus. Washington: U.S. Government Printing Office, 1973. (U.S. Department of Agriculture Agricultural Handbook, n. 427).

GRANUM, P. E.; O'SULLIVAN, K.; LUND, T. The sequence of the non-haemolytic enterotoxin operon from Bacillus cereus. FEMS Microbiology Letters, v. 177, p. 225-229, 1999.

GUINEBRETIÈRE, M. H.; BROUSSOLLE, V.; NGUYEN-THE, C. Enterotoxigenic profiles of food-poisoning and food-borne Bacillus cereus strains. Journal of Clinical Microbiology, v. 40, p. 3053-3056, 2002. http://dx.doi.org/10.1128/JCM.40.8.30533056.2002

HANSEN, B. M.; HENDRIKSEN, N. B. Detection of enterotoxin Bacillus cereus and Bacillus thuringiensis strains by PCR analysis. Applied and Environmental Microbiology, v. 67, p. 185-189, 2001. http://dx.doi.org/10.1128/AEM.67.1.185-189.2001

HARMON, S. M.; GOEPFERT, J. M.; BENNETT, R. W. Bacillus cereus. In: VANDERZANT, C.; SPLITTSTOESSER, F. Compendium of methods for the microbiological examination of foods. 3th ed. Washington: American Public Health Association, 1992. p. 593-604.

HSIEH, Y. M. et al. Enterotoxigenic profiles and polymerase chain reaction detection of Bacillus cereus groups cells and $B$. cereus strains from foods and food-borne outbreaks. Journal of Applied Microbiology, v. 87, p. 481-490, 1999. http://dx.doi.org/10.1046/ j.1365-2672.1999.00837.x

KOTIRANTA, A.; LOUNATMAA, K.; HAAPASALO, M. Epidemiology and pathogenesis of Bacillus cereus infections. Microbes Infect, v. 2, p. 189-198, 2000. http://dx.doi.org/10.1016/S1286-4579(00)00269-0
LUND, T.; GRANUM, P. E. Characterization of a non-haemolytic enterotoxin complex from Bacillus cereus isolated after a food borne outbreak. FEMS Microbiology Letters, v. 141, p. 151-156, 1996. PMid:8768516. http://dx.doi.org/10.1111/j.1574-6968.1996. tb08377.x

MÄNTYNEN, V.; LINDSTRÖM, K. M. A rapid PCR-based DNA test for enterotoxic Bacillus cereus. Applied and Environmental Microbiology, v. 64, p. 1634-1639, 1998. PMid:9572928. PMCid:106207.

MEAD, P. S. et al. Food-related illness and death in the United States. Emerging Infectious Diseases, v. 5, p. 607-625, 1999. PMid:10511517. PMCid:2627714. http://dx.doi.org/10.3201/ eid0505.990502

NUNES, E. L. C. et al. Detection of ileS-2 gene encoding mupirocin resistance in methicillin-resistant Sthaphylococccus aureus by multiplex PCR. Diagnostic Microbiology and Infectious Disease, v. 34, p. 77-81, 1999. http://dx.doi.org/10.1016/S07328893(99)00021-8

PHELPS, R. J.; MCKILLIP, J. L. Enterotoxin production in natural isolates of Bacillaceae outside the Bacillus cereus group. Applied and Environmental Microbiology, v. 68, p. 3147-3151, 2002. PMid:12039781. PMCid:123918. http://dx.doi.org/10.1128/ AEM.68.6.3147-3151.2002

PRÜSS, B. M. et al. The hemolytic enterotoxin HBL is broadly distributed among species of the Bacillus cereus group. Applied and Environmental Microbiology, v. 65, p. 5436-5442, 1999.

ROSENQUIST, H. et al. Occurrence and significance of Bacillus cereus and Bacillus thuringiensis in ready-to-eat food. FEMS Microbiology Letters, v. 250, p. 129-136, 2005. PMid:16043311. http://dx.doi. org/10.1016/j.femsle.2005.06.054

RYAN, P. A.; MCMILLAN, J. D.; ZILINSKAS, B. A. Molecular cloning and characterization of the genes encoding the $\mathrm{L}_{1}$ and $\mathrm{L}_{2}$ components hemolysin BL from Bacillus cereus. Journal of Bacteriology, v. 179, p. 2551-2556, 1997.

SILVA, N. et al. Bacillus cereus. In: SILVA, N. et al. Manual de métodos de análise microbiológica de alimentos. São Paulo: Livraria Varela, 2007. p. 149-160.

SIMONE, E. et al. Investigations of foodborne diseases by food inspection services in The Netherlands, 1991-1994. Journal of Food Protection, v. 60, p. 442-446, 1997.

SPECK, L. M. Compendium of methods for the microbiological examination of foods. 2 th ed. Washington: American Public Health Association, 1984.

TSEN, H. Y. et al. Bacillus cereus group strains, their hemolysin BL activity, and their detection in foods using a 16s RNA and hemolysin BL gene-targeted multiplex polymerase chain reaction system. Journal of Food Protection, v. 63, p. 1496-1502, 2000.

VALERO, M. et al. Characterization of Bacillus cereus isolates from fresh vegetables and refrigerated minimally processed foods by biochemical and physiological tests. Food Microbiology, v. 19, p. 491-499, 2002. http://dx.doi.org/10.1006/fmic.2002.0507

VASCONCELOS, F. J. M.; RABINOVITCH, L. A new for an alternative culture medium, without

antibiotics, for isolation and presumptive quantification of Bacillus cereus in food. Journal of Food Microbiology, v. 58, p. 235-238, 1994.

YEN, W. J. et al. Antioxidant properties of roasted coffee residues. Journal of Agricultural and Food Chemistry, v. 53, p. 2658-63, 2005. PMid:15796608. http://dx.doi.org/10.1021/jf0402429 